\title{
Facile and Scalable Methodology for the Pyrrolo[2,1-f][1,2,4]triazine of Remdesivir
}

\author{
${ }^{\dagger}$ Sarabindu Roy, ${ }^{\dagger}$ Ajay Yadaw, ${ }^{\dagger}$ Subho Roy, ${ }^{\S}$ Gopal Sirasani, ${ }^{\S}$ Joseph D. Armstrong III, *B. Frank Gup- \\ ton, ${ }^{\circledR}$ Chris H. Senanayake*, and ${ }^{\circ}$ David R. Snead*
}

\begin{abstract}
Pyrrolo[2,1-f][1,2,4]triazine (1) is an important regulatory starting material in the production of Remdesivir (Vekluryß). Compound 1 was produced through a newly developed synthetic methodology utilizing the simple building blocks pyrrole, chloramine and formamidine acetate by examining the mechanistic pathway for the process optimization exercise. Triazine 1 was obtained in 55\% overall yield in a two-reactor operated process. This work describes the safety of the process, impurity profiles and control, and efforts towards the scale-up of triazine for the preparation of kilogram quantity.
\end{abstract}

Keywords: Antiviral agents • API • Remdesivir • Triazine • Supply centered synthesis

\section{- Introduction}

The process research community has embarked on rapid development of a practical commercial route to remdesivir since it emerged as a COVID-19 therapeutic. ${ }^{1,2}$ We recently published a route to construct pyrrolo[2,1-f][1,2,4]triazine (1) from commodity starting materials ${ }^{3}$ and the retrosynthetic analysis of the triazine 1 as shown in Figure 1. 2,5-Dimethoxytetrahydrofuran, tert-butylcarbazate, and chlorosulfonyl isocyanate were replaced with the readily available pyrrole, dimethylformamide, hydroxylamine, ammonia and bleach in an effort to secure supply of this important regulatory starting material 1. ${ }^{4}$ In addition to proceeding from low-cost raw materials, this procedure also increased overall yield from $33 \%$ to $55 \%$ as shown in Figure 2. Triazine $\mathbf{1}$ is a key component of remdesivir, a COVID-19 treatment, and its use occurs at the outset of a convergent synthesis, thus necessitating a sustainable manufacturing process of compound $1 .^{1}$

Our recent publication highlighted the feasibility of assembling the triazine moiety from pyrrole and other commodity chemicals. ${ }^{3}$ This work describes our process research and development program followed by scale-up and feasibility studies for large scale operation. Furthermore, scale-up implementation, safety concerns, removal of impurities generated during the synthetic process development, and ability to make substantial quantities of high quality triazine $\mathbf{1}$ are addressed. To this end, $1 \mathrm{~kg}$ of triazine was made via this two-reactor operation.

\section{- Safety Studies: Thermochemical Analysis of Cyanation and Amination}

Understanding the process safety profile was a primary objective prior to further implementation of this chemistry at scale. The first reaction sequence contains an exothermic aromatic substitution and quench of reactive species, ${ }^{5}$ and the second sequence involves the use of a strong base, sodium hydride in conjunction with $N, N$-dimethylformamide, potentially an explosive combination. ${ }^{6}$

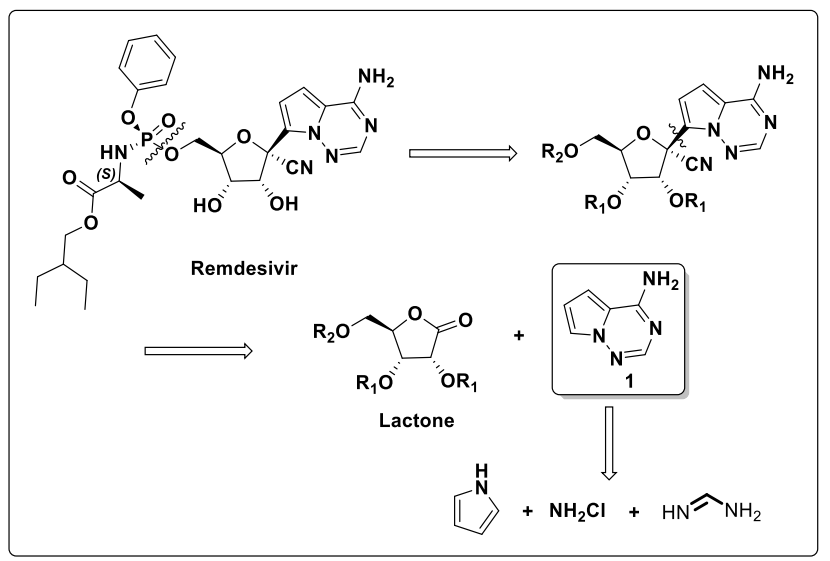

Figure 1: A retrosynthetic analysis of remdesivir from subunits lactone and triazine $\mathbf{1}$.

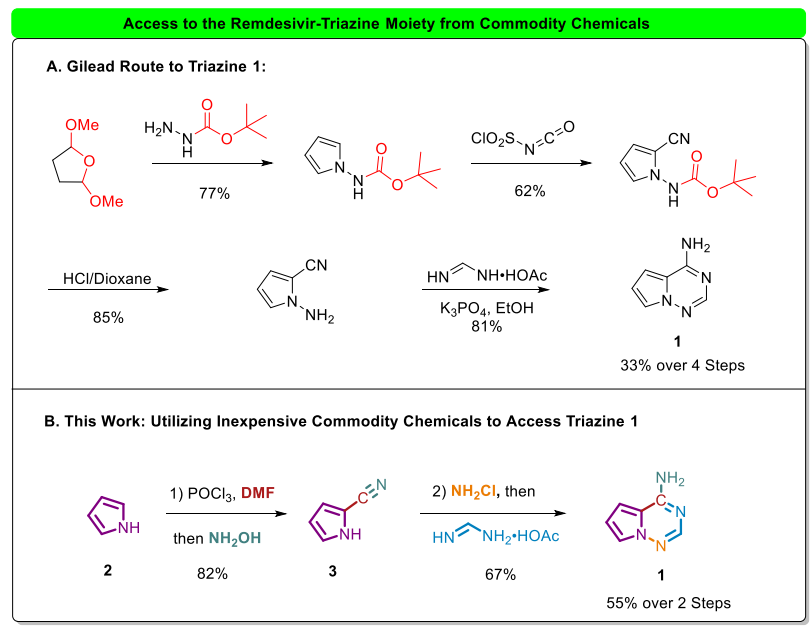

Figure 2: Current route to make the triazine 1. 
Monochloramine, which has the potential to decompose to toxic and explosive trichloramine, ${ }^{7}$ was generated in situ. For these reasons we have developed a safe and robust method for on demand production and immediate consumption of this reagent to minimize the build-up of any hazardous materials.

Reaction calorimetry was chosen to evaluate the safety profile of the cyanation reaction. First, $50 \mathrm{~g}$ of pyrrole (1) was dissolved in $500 \mathrm{~mL}$ of DMF and the subsequent reactions were studied in an RC-1 reactor. The cyanation was examined incrementally at each stage of the reaction, including generation of the Vilsmeier reagent (4), addition of pyrrole, quench of phosphoryl chloride species (5) with water, and hydroxylamine addition, followed by treatment with acetic anhydride, pyridine, sodium acetate or combinations thereof to obtain the best thermal properties of the reaction mixture and quench protocol (Tables 1-5). It is important to note that acetic anhydride was found to be the best choice for the quench protocol.

Generation of the Vilsmeier reagent (4) was exothermic $\left(\Delta \mathrm{T}_{\mathrm{ad}}\right.$ $30.40{ }^{\circ} \mathrm{C}$, Table 1) and the maximum temperature of reaction (MTSR) also low $\left(30.40{ }^{\circ} \mathrm{C}\right)$. Since the MTSR value is well below the MTT (boiling point of solvent), it showed low severity as per Stoessel's Rules. Moreover, no thermal accumulation of heat was observed, therefore, the overall data package projects this to be a safe process for scale-up operation.

Addition of pyrrole to the Vilsmeier reagent (4) showed more exotherm (Table 2) as $\Delta \mathrm{T}_{\mathrm{ad}}$ is $84^{\circ} \mathrm{C}$. The maximum attainable temperature is $84^{\circ} \mathrm{C}$, which is below the MTT and hence severity is low. The reaction is quite rapid with high conversion upon completion of the dosing $(98 \%)$. By diluting the reaction from 5 volumes $\left(\Delta \mathrm{T}_{\mathrm{ad}} 179^{\circ} \mathrm{C}\right)$ to 10 volumes of $\mathrm{DMF}\left(\Delta \mathrm{T}_{\mathrm{ad}} 84.5^{\circ} \mathrm{C}\right)$ the safety hazard of the reaction is controlled.

Quenching of the phosphoryl chloride species (5) was conducted by addition of water at $0{ }^{\circ} \mathrm{C}$ after acylation of the pyrrole (Table 3). The MTSR was significantly below the MTT $\left(46^{\circ} \mathrm{C}\right.$ vs. $152{ }^{\circ} \mathrm{C}$ ), and as importantly, thermal conversion was nearly complete by the end of addition (98\%), thus reducing the risk of delayed heat release from the unquenched reactive species. Continuous flow presents excellent performance in handling and scaling exothermic reactions. Options exist for handling the sequence of Vilsmeier reagent formation, electrophilic aromatic substitution of pyrrole, and quench of phosphoryl chloride species. $^{8}$ This can be used to further decrease risk associated with scaling this process.

The last step of the acid quench and formation of the nitrile from the iminium chloride was essentially complete at the end of reagent addition evolving $96.5 \%$ of heat, as oxidation to the nitrile was not a fast reaction (Table 4). Also, this step was the least exotherm of the sequence. In order to obtain the optimal thermal profile, we examined several quench protocols with the hydroxylamine addition process. As shown in Tables 5 and 6, pyridine and acetic anhydride quench protocols were examined. It is important to note that the acetic anhydride quench protocol provided the optimum process parameters for the scale-up and thermal properties of this reaction.

Next, the amination was also examined calorimetrically to assess the risks associated with the combination of $\mathrm{NaH}$ and DMF. Sodium hydride (19.13 g, 60\%) was added to DMF (400 $\mathrm{mL}$ ) at $3{ }^{\circ} \mathrm{C}$ to generate $2.87 \%$ dispersion and a mild adiabatic temperature rise of $0.14{ }^{\circ} \mathrm{C}$ was observed. Afterwards, 2-cyanopyrrole $(3,40 \mathrm{~g})$ was added to the $\mathrm{NaH}$ dispersion which was immediately deprotonated by the base, generating 7 . The adiabatic temperature rise was $55^{\circ} \mathrm{C}$, and the MTSR $\left(58^{\circ} \mathrm{C}\right)$ as the reaction was performed at $0{ }^{\circ} \mathrm{C}$. MTSR is found to be less than the MTT $\left(152{ }^{\circ} \mathrm{C}\right)$ and hence it is safe to handle. There is nominal thermal accumulation $(\sim 6 \%)$ after the dosing of 2-cyanopyrrole (3). This renders the reaction a low safety risk for scale up to produce $\mathbf{8}$.

A residual 0.1 equiv. of unreacted $\mathrm{NaH}(1.04 \mathrm{~g})$ is present in $\sim 40 \mathrm{~mL}$ of reaction mass, which is equivalent to approximately $0.24 \mathrm{wt} \% \mathrm{NaH}$ in DMF. Chloramine is acidic (pKa 14$)^{9}$ which consumes the remaining base. Onset of exothermic events is tied to the concentration of $\mathrm{NaH}$ in $\mathrm{DMF}$, and recent studies show that the thermal runaway occurs at 10-26 wt $\%$ of $\mathrm{NaH}$ in DMF. ${ }^{6}$ In this process, the concentration is sufficiently below or negligible for the defined runaway window. The subsequent reaction with monochloramine is only mildly exothermic. Therefore, the process we defined is well suited for further scale-up operations according to the examined parameters.

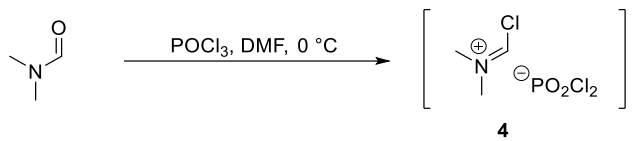

Table 1: Thermochemical analysis of $\mathrm{POCl}_{3}$ addition to DMF at $0{ }^{\circ} \mathrm{C}$.

\begin{tabular}{cc}
\hline RC parameters & Results \\
\hline Heat generated & $\begin{array}{c}49.08 \mathrm{~kJ} / 50 \text { g of pyrrole } \\
65.88 \mathrm{~kJ} / \mathrm{mol} \text { of pyrrole }\end{array}$ \\
\hline Adiabatic temp. rise $(\mathrm{K})$ & 30.40 \\
\hline MTSR $\left({ }^{\circ} \mathrm{C}\right)$ & 30.40 \\
\hline MTT $\left({ }^{\circ} \mathrm{C}\right)$ & 152 \\
\hline $\begin{array}{c}\text { Thermal accumulation } \\
\text { at the end of dosing }\end{array}$ & $1.80 \%$ \\
\hline $\begin{array}{c}\text { Thermal conversion at } \\
\text { the end of dosing }\end{array}$ & $98.20 \%$ \\
\hline $\begin{array}{c}\text { Specific heat before ad- } \\
\text { dition }\left(\mathrm{kJ} \cdot \mathrm{kg}^{-1} \cdot \mathrm{K}^{-1}\right)\end{array}$ & 2.83 \\
\hline $\begin{array}{c}\text { Specific heat after addi- } \\
\text { tion }\left(\mathrm{kJ} \cdot \mathrm{kg}^{-1} \cdot \mathrm{K}^{-1}\right)\end{array}$ & 2.69 \\
\hline
\end{tabular}

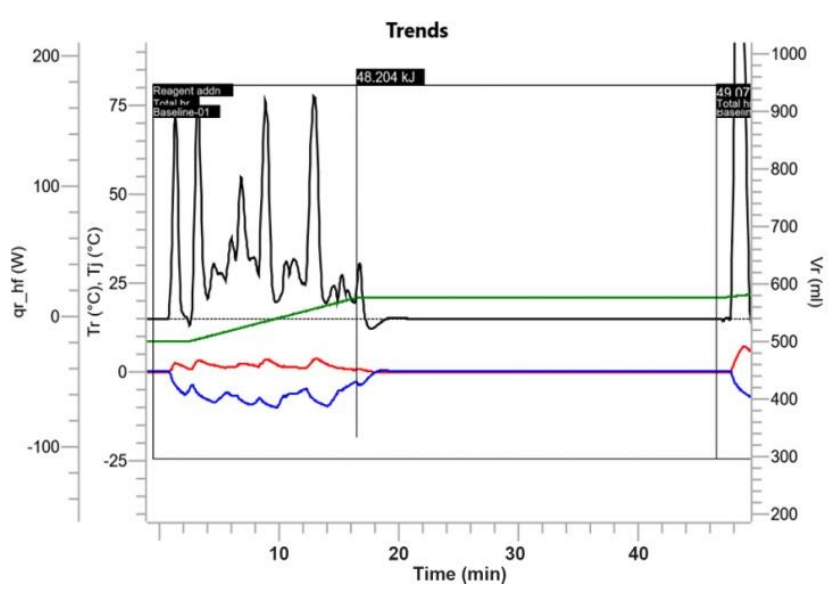

RC1 analysis, Graph 01: $\mathrm{POCl}_{3}$ addition at $0{ }^{\circ} \mathrm{C}$

\begin{tabular}{|l|l|l|l|}
\hline Trend & Color & Axis & Units \\
\hline $\mathrm{Tr}$ & & 2 & ${ }^{\circ} \mathrm{C}$ \\
\hline $\mathrm{Tj}$ & & 2 & ${ }^{\circ} \mathrm{C}$ \\
\hline $\mathrm{qr}$ hf & & 1 & $\mathrm{~W}$ \\
\hline $\mathrm{Vr}$ & & 3 & $\mathrm{ml}$ \\
\hline
\end{tabular}




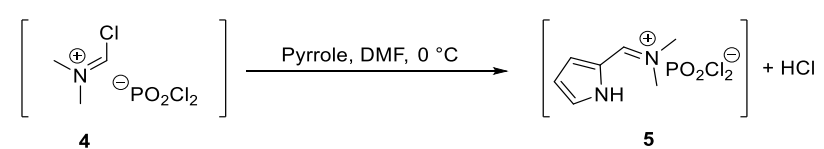

Table 2: Thermochemical analysis of addition of pyrrole to Vilsmeier's reagent in DMF.

\begin{tabular}{cc}
\hline RC parameters & Results \\
\hline Heat generated & $\begin{array}{c}144.73 \mathrm{~kJ} / 50 \text { g pyrrole } \\
194.27 \mathrm{~kJ} / \mathrm{mol} \text { pyrrole }\end{array}$ \\
\hline Adiabatic temp. rise $(\mathrm{K})$ & 84.54 \\
\hline MTSR $\left({ }^{\circ} \mathrm{C}\right)$ & 84.54 \\
MTT $\left({ }^{\circ} \mathrm{C}\right)$ & 152 \\
\hline $\begin{array}{c}\text { Thermal accumulation } \\
\text { at the end of dosing }\end{array}$ & $0.80 \%$ \\
\hline $\begin{array}{c}\text { Thermal conversion at } \\
\text { the end of dosing }\end{array}$ & $99.80 \%$ \\
\hline $\begin{array}{c}\text { Specific heat before ad- } \\
\text { dition }\left(\mathrm{kJ} \cdot \mathrm{kg}^{-1} \cdot \mathrm{K}^{-1}\right)\end{array}$ \\
\hline $\begin{array}{c}\text { Specific heat after addi- } \\
\text { tion }\left(\mathrm{kJ} \cdot \mathrm{kg}^{-1} \cdot \mathrm{K}^{-1}\right)\end{array}$ \\
\hline
\end{tabular}

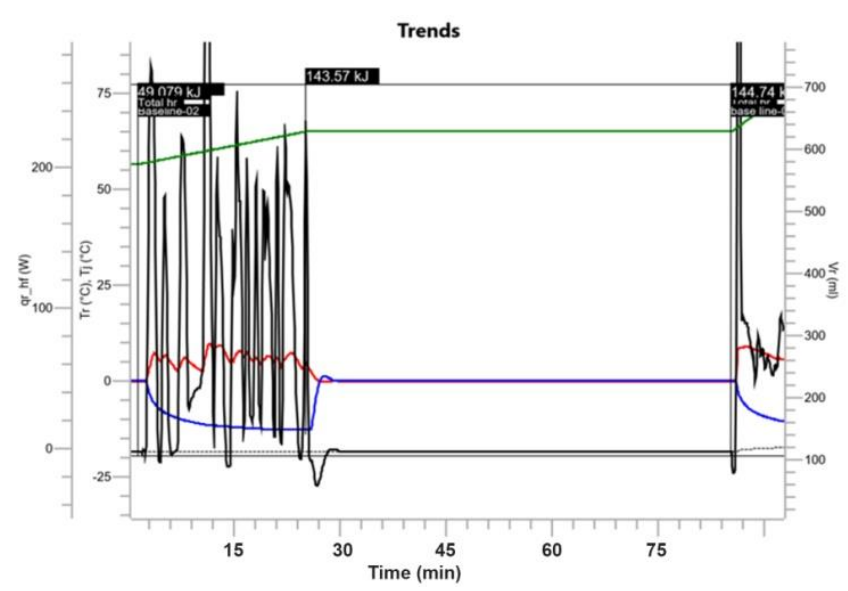

RC1 Graph 02: 1 -H-pyrrole addition at $0{ }^{\circ} \mathrm{C}$.

\begin{tabular}{|l|l|l|l|}
\hline Trend & Color & Axis & Units \\
\hline $\mathrm{Tr}$ & & 2 & ${ }^{\circ} \mathrm{C}$ \\
\hline $\mathrm{Tj}$ & & 2 & ${ }^{\circ} \mathrm{C}$ \\
\hline $\mathrm{gr} / \mathrm{hf}$ & & 1 & $\mathrm{~W}$ \\
\hline $\mathrm{Vr}$ & & 3 & $\mathrm{ml}$ \\
\hline
\end{tabular}

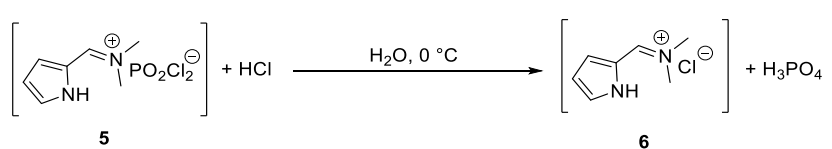

Table 3: Thermochemical analysis of addition of water to unquenched phosphoryl chloride species.

\begin{tabular}{|c|c|}
\hline RC parameters & Results \\
\hline Heat generated & $\begin{array}{l}91.90 \mathrm{~kJ} / 50 \mathrm{~g} \text { pyrrole } \\
123.35 \mathrm{~kJ} / \mathrm{mol} \text { pyrrole }\end{array}$ \\
\hline Adiabatic temp. rise (K) & 46.63 \\
\hline $\operatorname{MTSR}\left({ }^{\circ} \mathrm{C}\right)$ & 46.63 \\
\hline $\operatorname{MTT}\left({ }^{\circ} \mathrm{C}\right)$ & 152 \\
\hline $\begin{array}{l}\text { Thermal accumulation at } \\
\text { the end of dosing }\end{array}$ & $1.86 \%$ \\
\hline $\begin{array}{l}\text { Thermal conversion at } \\
\text { the end of dosing }\end{array}$ & $98.14 \%$ \\
\hline $\begin{array}{l}\text { Specific heat before addi- } \\
\text { tion }\left(\mathrm{kJ} \cdot \mathrm{kg}^{-1} \cdot \mathrm{K}^{-1}\right)\end{array}$ & 2.63 \\
\hline $\begin{array}{l}\text { Specific heat after addi- } \\
\text { tion }\left(\mathrm{kJ} \cdot \mathrm{kg}^{-1} \cdot \mathrm{K}^{-1}\right)\end{array}$ & 2.46 \\
\hline
\end{tabular}

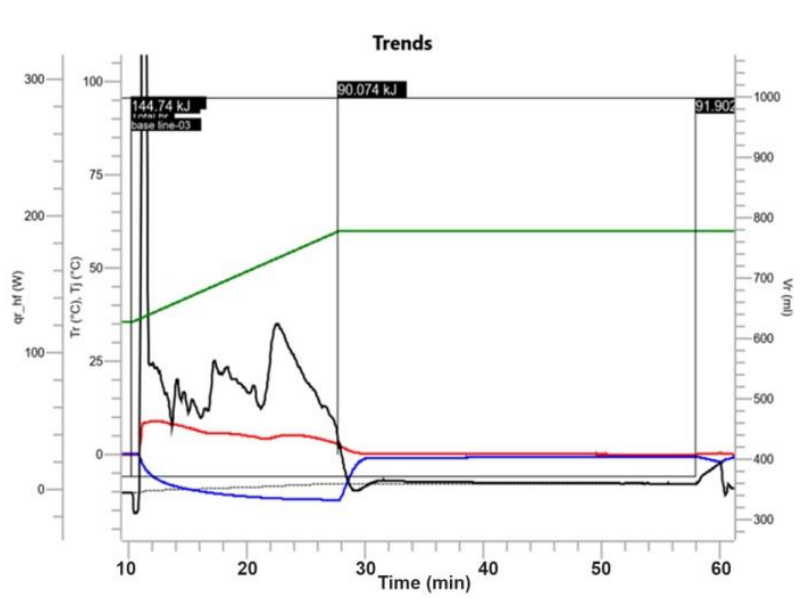

RC1 Graph 03: Water addition at $0{ }^{\circ} \mathrm{C}$.

\begin{tabular}{|l|l|l|l|}
\hline Trend & Color & Axis & Units \\
\hline $\mathrm{Tr}$ & & 2 & ${ }^{\circ} \mathrm{C}$ \\
\hline $\mathrm{Tj}$ & & 2 & ${ }^{\circ} \mathrm{C}$ \\
\hline $\mathrm{gr} \_\mathrm{hf}$ & & 1 & $\mathrm{~W}$ \\
\hline $\mathrm{Vr}$ & & 3 & $\mathrm{ml}$ \\
\hline
\end{tabular}


$\left[\underset{\mathrm{NH}}{\stackrel{\oplus}{N}{ }_{\mathrm{N}}^{\prime} \mathrm{Cl}^{\ominus}}\right]+\mathrm{H}_{3} \mathrm{PO}_{4} \stackrel{\mathrm{NH}_{2} \mathrm{OH} \cdot \mathrm{HCl} \text { (1.2 equiv.), } 0^{\circ} \mathrm{C}}{\longrightarrow}$

6

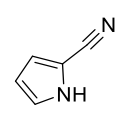

3

Table 4: Thermochemical analysis of addition of hydroxylamine $\mathrm{HCl}$.

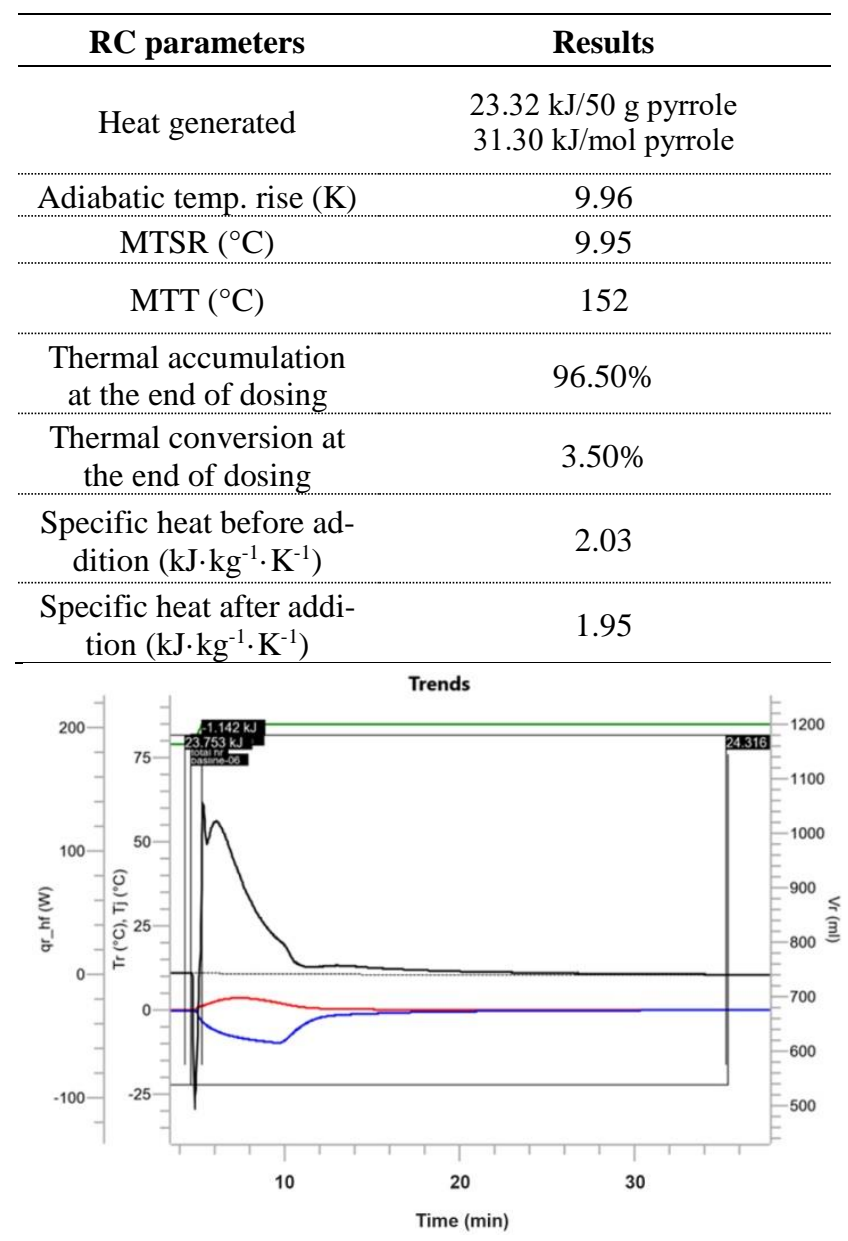

RC1 Graph 04: $\mathrm{NH}_{2} \mathrm{OH} \cdot \mathrm{HCl}$ addition at $0{ }^{\circ} \mathrm{C}$.

\begin{tabular}{|l|l|l|l|}
\hline Trend & Color & Axis & Units \\
\hline $\mathrm{Tr}$ & & 2 & ${ }^{\circ} \mathrm{C}$ \\
\hline $\mathrm{Tj}$ & & 2 & ${ }^{\circ} \mathrm{C}$ \\
\hline $\mathrm{qr}$ hf & & 1 & $\mathrm{~W}$ \\
\hline $\mathrm{Vr}$ & & 3 & $\mathrm{ml}$ \\
\hline
\end{tabular}

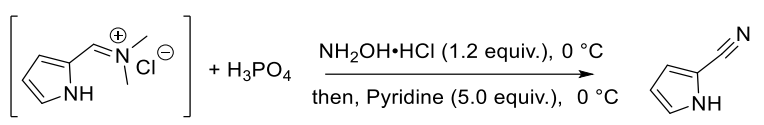
6

Table 5: Thermochemical analysis of addition of pyridine to acidic iminium chloride.

\begin{tabular}{cc}
\hline RC parameters & Results \\
Heat generated & $\begin{array}{c}160.52 \mathrm{~kJ} / 50 \text { g pyrrole } \\
215.46 \mathrm{~kJ} / \mathrm{mol} \text { pyrrole }\end{array}$ \\
\hline Adiabatic temp. rise $(\mathrm{K})$ & 68.85 \\
\hline MTSR $\left({ }^{\circ} \mathrm{C}\right)$ & 68.85 \\
MTT $\left({ }^{\circ} \mathrm{C}\right)$ & 152 \\
\hline $\begin{array}{c}\text { Thermal accumulation at } \\
\text { the end of dosing }\end{array}$ & $0 \%$ \\
\hline $\begin{array}{c}\text { Thermal conversion at } \\
\text { the end of dosing }\end{array}$ & $100 \%$ \\
\hline $\begin{array}{c}\text { Specific heat before addi- } \\
\text { tion }\left(\mathrm{kJ} \cdot \mathrm{kg}^{-1} \cdot \mathrm{K}^{-1}\right)\end{array}$ & 2.46 \\
\hline $\begin{array}{c}\text { Specific heat after addi- } \\
\text { tion }\left(\mathrm{kJ} \cdot \mathrm{kg}^{-1} \cdot \mathrm{K}^{-1}\right)\end{array}$ & 2.13 \\
\hline
\end{tabular}

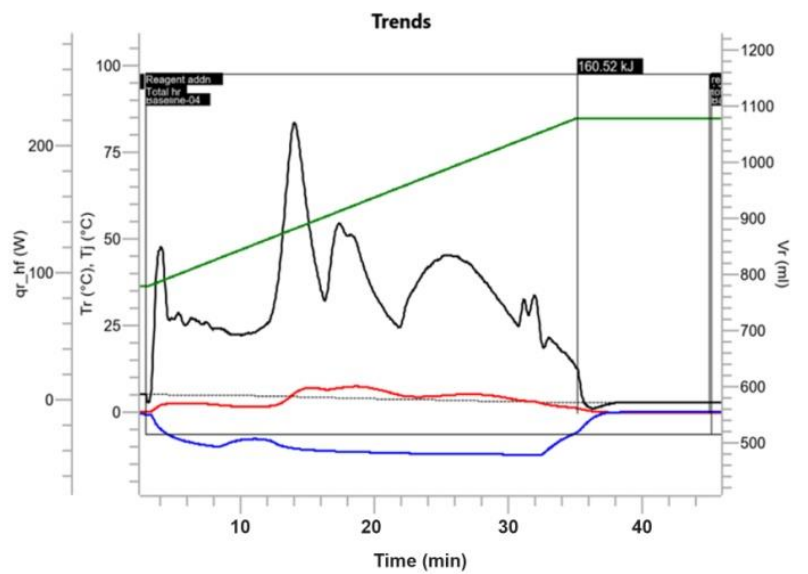

RC1 Graph 05: Pyridine addition at $0{ }^{\circ} \mathrm{C}$.

\begin{tabular}{|l|l|l|l|}
\hline Trend & Color & Axis & Units \\
\hline $\mathrm{Tr}$ & & 2 & ${ }^{\circ} \mathrm{C}$ \\
\hline $\mathrm{Tj}$ & & 2 & ${ }^{\circ} \mathrm{C}$ \\
\hline $\mathrm{qr}$ hf & & 1 & $\mathrm{~W}$ \\
\hline $\mathrm{Vr}$ & & 3 & $\mathrm{ml}$ \\
\hline
\end{tabular}




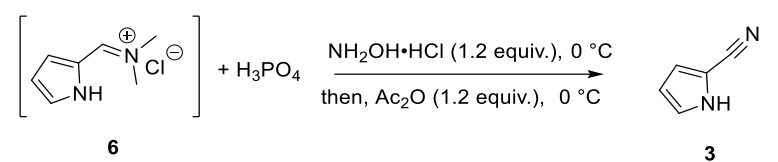

Table 6: Thermochemical analysis of addition of acetic anhydride.

\begin{tabular}{cc}
\hline RC parameters & Results \\
\hline Heat generated & $\begin{array}{l}23.75 \mathrm{~kJ} / 50 \text { g pyrrole } \\
31.88 \mathrm{~kJ} / \mathrm{mol} \text { pyrrole }\end{array}$ \\
\hline Adiabatic temp. rise $(\mathrm{K})$ & 9.88 \\
\hline MTSR $\left({ }^{\circ} \mathrm{C}\right)$ & 9.88 \\
\hline MTT $\left({ }^{\circ} \mathrm{C}\right)$ & 152 \\
\hline $\begin{array}{c}\text { Thermal accumulation } \\
\text { at the end of dosing } \\
\text { the end of dosing }\end{array}$ & $1.85 \%$ \\
\hline $\begin{array}{c}\text { Thermal conversion at } \\
\text { Specific heat before ad- } \\
\text { dition }\left(\mathrm{kJ} \cdot \mathrm{kg}^{-1} \cdot \mathrm{K}^{-1}\right)\end{array}$ & $98.15 \%$ \\
\hline $\begin{array}{c}\text { Specific heat after addi- } \\
\text { tion }\left(\mathrm{kJ} \cdot \mathrm{kg}^{-1} \cdot \mathrm{K}^{-1}\right)\end{array}$ & 2.13 \\
\hline
\end{tabular}

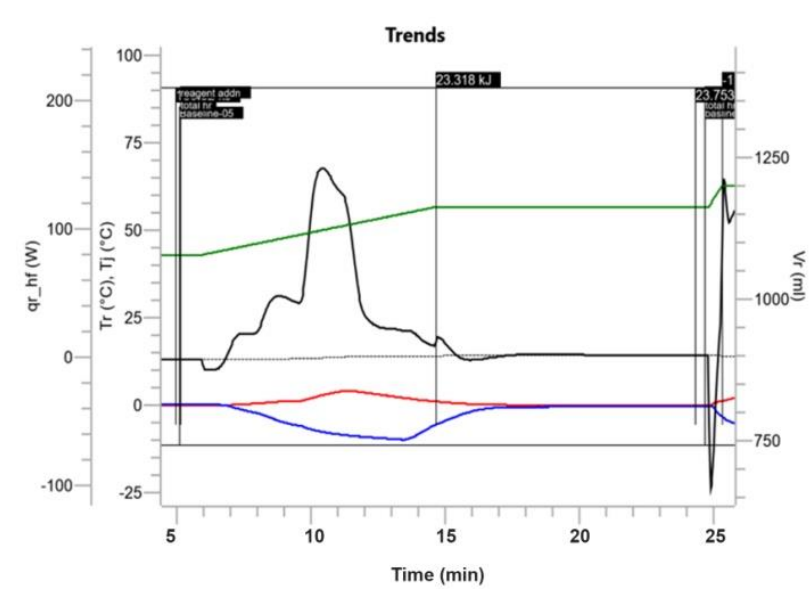

RC1 Graph 07: Acetic Anhydride addition at $0{ }^{\circ} \mathrm{C}$.

\begin{tabular}{|l|l|l|l|}
\hline Trend & Color & Axis & Units \\
\hline $\mathrm{Tr}$ & & 2 & ${ }^{\circ} \mathrm{C}$ \\
\hline $\mathrm{Tj}$ & & 2 & ${ }^{\circ} \mathrm{C}$ \\
\hline $\mathrm{qr} \_\mathrm{hf}$ & & 1 & $\mathrm{~W}$ \\
\hline $\mathrm{Vr}$ & & 3 & $\mathrm{ml}$ \\
\hline
\end{tabular}

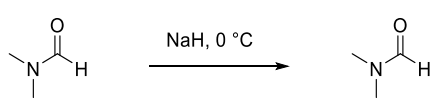

Table 7: Thermochemical analysis of sodium hydride in DMF.

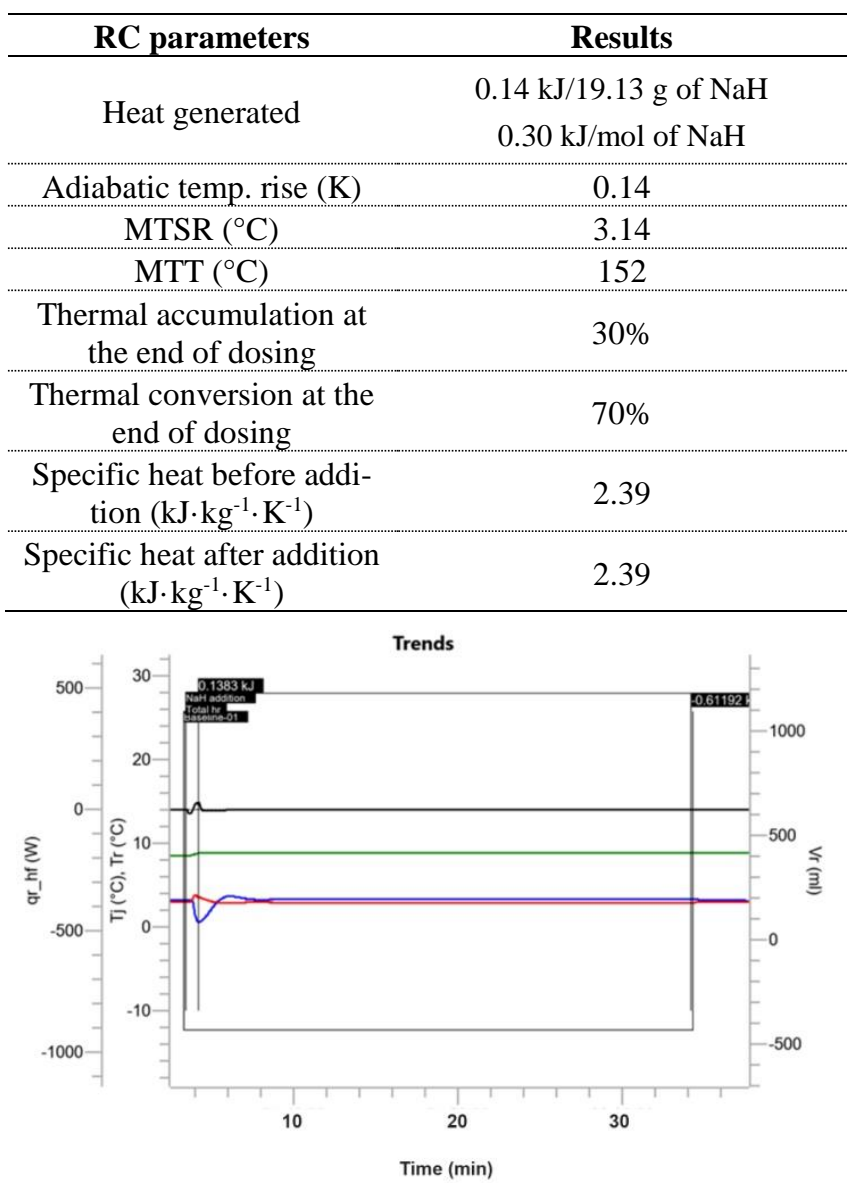

RC1 Graph 07: Sodium hydride addition at $0{ }^{\circ} \mathrm{C}$.

\begin{tabular}{|l|l|l|l|}
\hline Trend & Color & Axis & Units \\
\hline $\mathrm{Tr}$ & & 2 & ${ }^{\circ} \mathrm{C}$ \\
\hline $\mathrm{Tj}$ & & 2 & ${ }^{\circ} \mathrm{C}$ \\
\hline $\mathrm{qr}$ hf & & 1 & $\mathrm{~W}$ \\
\hline $\mathrm{Vr}$ & & 3 & $\mathrm{ml}$ \\
\hline
\end{tabular}




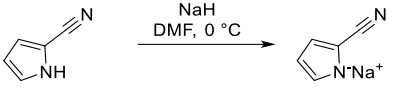

3 7

Table 8: Thermochemical analysis of addition of 2-cyanopyrrole.

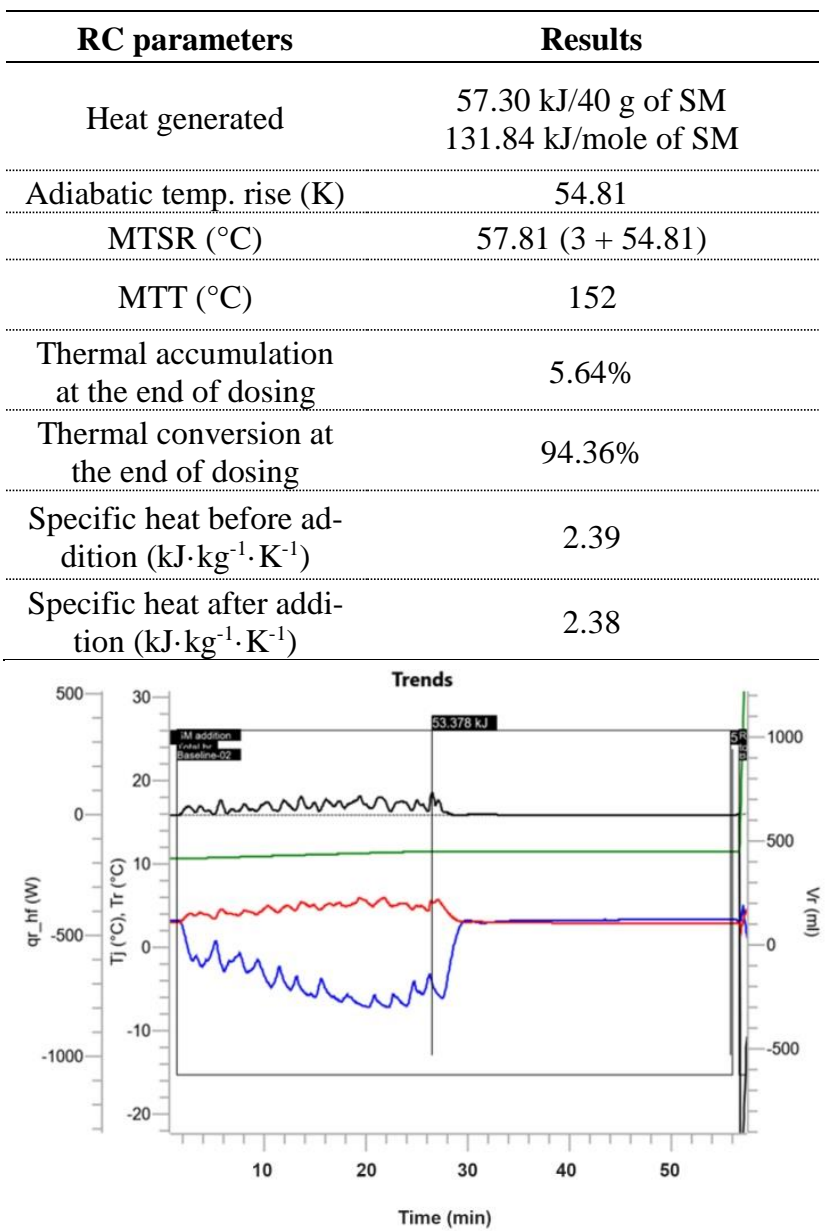

RC1 Graph 08: 2-cyano pyrrole addition at $3{ }^{\circ} \mathrm{C}$

\begin{tabular}{|l|l|l|l|}
\hline Trend & Color & Axis & Units \\
\hline $\mathrm{Tr}$ & & 2 & ${ }^{\circ} \mathrm{C}$ \\
\hline $\mathrm{Tj}$ & & 2 & ${ }^{\circ} \mathrm{C}$ \\
\hline $\mathrm{qr} \_\mathrm{hf}$ & & 1 & $\mathrm{~W}$ \\
\hline $\mathrm{Vr}$ & & 3 & $\mathrm{ml}$ \\
\hline
\end{tabular}

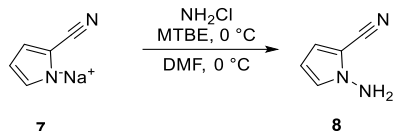

Table 9: Thermochemical analysis of addition of $\mathrm{NH}_{2} \mathrm{Cl}$ in MTBE Solution.

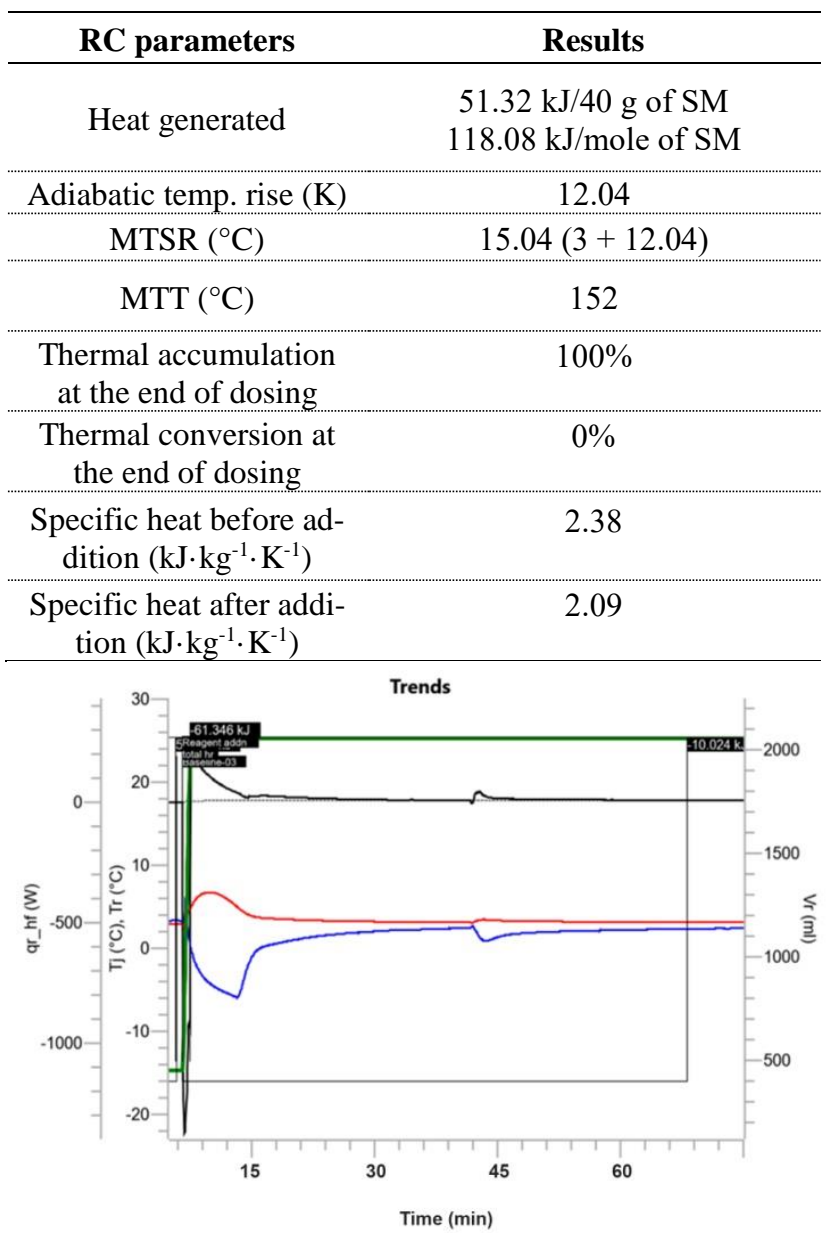

RC1 Graph 09: $\mathrm{NH}_{2} \mathrm{Cl}$ in MTBE Solution addition at $0{ }^{\circ} \mathrm{C}$.

\begin{tabular}{|l|l|l|l|}
\hline Trend & Color & Axis & Units \\
\hline $\mathrm{Tr}$ & & 2 & ${ }^{\circ} \mathrm{C}$ \\
\hline $\mathrm{Tj}$ & & 2 & ${ }^{\circ} \mathrm{C}$ \\
\hline $\mathrm{qr}$ hf & & 1 & $\mathrm{~W}$ \\
\hline $\mathrm{Vr}$ & & 3 & $\mathrm{ml}$ \\
\hline
\end{tabular}

\section{- Impurities Analysis and Control}

In order to ensure the production of high-quality and high yield of triazine 1, we undertook the identification of the impurities generated throughout the synthetic process and optimized the reaction conditions to minimize these impurities. 


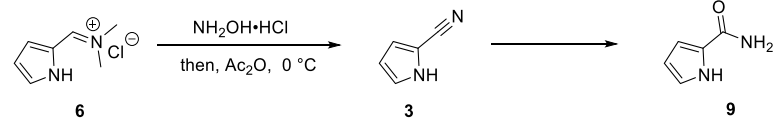

B. Amination: N-Amino-pyrrole Reverts to Product and Chlorinates
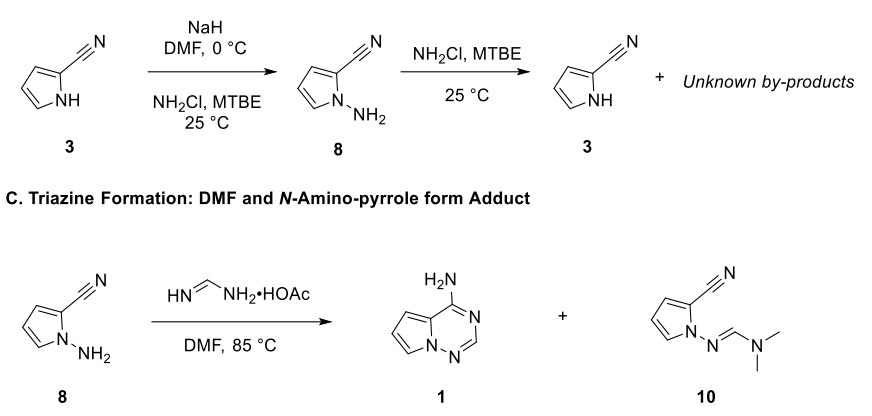

Figure 3: Products and impurities.

Fortunately, due to the high-yielding nature and defined reaction conditions of the synthetic process, limited by-product formation was observed. In the cyanation reaction, 1-H-pyrrole-2carboxamide (9) was the major impurity detected, likely a byproduct formed under acidic conditions in the presence of water. To minimize formation of 1-H-pyrrole-2-carboxamide (9), we determined that the dilution effect was important. The increase in the dilution of the reaction (9\% 1-H-pyrrole-2-carboxamide at 5V DMF to $2.57 \%$ 1-H-pyrrole-2-carboxamide at $15 \mathrm{~V}$ DMF) (Table 10) reduced the formation of 9 to a minimum level.

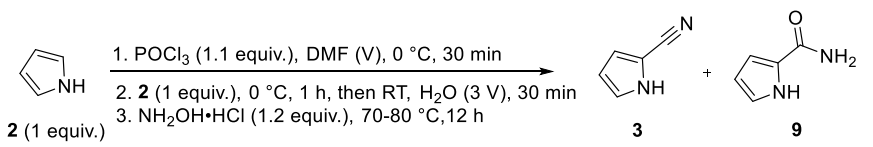

Table 10: Reaction dilutions vs. amide 9 formation.

\begin{tabular}{cccc}
\hline & DMF & & \\
Entry & $(\mathbf{V}, \mathbf{m L})$ & Yield (A \%) & Amide 9 (A\%) \\
\hline 1 & 5 & 87 & 9 \\
2 & 10 & 95 & 3.5 \\
3 & 15 & 96 & 2.7 \\
\hline
\end{tabular}

It was observed that some polymeric material was formed during the course of this reaction. ${ }^{8,10}$ This material appeared as dark brown to black particles in the work-up of the 2-cyanopyrrole. Judicious selection of work-up conditions was critical in preventing the particles from causing difficulty in the separation of the aqueous and organic layers during the work-up process and is explained in detail in the experimental procedure.

The major by-product in aminating 3 with $\mathrm{NH}_{2} \mathrm{Cl}$ is actually reversion of $\mathrm{N}$-amino-2-cyanopyrrole $\mathbf{8}$ back to 2-cyanopyrrole (Figure 3, B). This occurs when an excess of chloramine is introduced into the system after all 2-cyanopyrrole (3) is converted to $\mathrm{N}$-amino-2-cyanopyrrole $\mathbf{8}$ (Table 11 ). It is noteworthy that this phenomenon is precedented. ${ }^{11}$ Moreover, $N$-amino2-cyanopyrrole (8) afforded $\sim 20 \%$ of 2-cyanopyrrole (3) when treated with $\mathrm{NH}_{2} \mathrm{Cl}$ in absence of any base. This reversal process can be controlled by monitoring the conversion to product during the last $20 \%$ of the controlled addition of chloramine to the reaction mixture. By carefully monitoring the presence of excess $\mathrm{NH}_{2} \mathrm{Cl}$ as well as the basicity of the reaction mass, $\mathrm{NH}_{2} \mathrm{Cl}$ can be introduced in small portions (continuous feeding) which in turn can control the reversal process to a minimum level $(<2 \%$, see experimental procedure).

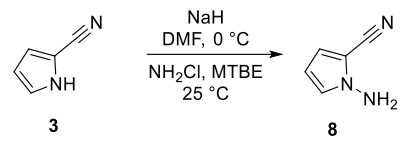

Table 11: Dependency of reaction outcome on chloramine stoichiometry.

\begin{tabular}{ccccc}
\hline $\begin{array}{c}\text { NH} \mathbf{C l} \\
\text { (Vol- } \\
\text { umes) }\end{array}$ & $\begin{array}{c}\mathbf{3} \\
(\mathbf{A} \%)\end{array}$ & $\begin{array}{c}\mathbf{8} \\
(\mathbf{A} \%)\end{array}$ & $\begin{array}{c}\text { Impurities } \\
(\mathbf{A} \%)\end{array}$ & $\begin{array}{c}\mathbf{3 + 8} \\
(\mathbf{A} \%)\end{array}$ \\
\hline 17 & 64 & 30 & - & 94 \\
27 & 17 & 74 & - & 91 \\
37 & 15 & 81 & - & 96 \\
47 & 53 & 15 & 18,5 & 68 \\
\hline
\end{tabular}

During formation of the 1,2,4 triazine $\mathbf{1}$ with formamidine acetate in the last stage of the sequence, an adduct $\mathbf{1 0}$ was produced by the condensation of amino pyrrole 7 with DMF. This impurity was formed up to $5 \%$ by HPLC (A\%). It is important to note that, this impurity can be rejected under the defined work-up and crystallization conditions. Once the reaction is completed, water was added to the reaction mixture to precipitate product, and once filtered, the crude product contained $>3 \%$ of impurity 10. The final purification with MTBE completely purged 10, and product was obtained $\mathbf{1}$ was obtained with purity of $99.80 \%$ (see the experimental details). ${ }^{12}$

\section{- Scale-Up of 2-Cyanopyrrole (3) and Triazine (1):}

The viability of the above discussed synthetic protocol for the preparation of triazine 1 was first demonstrated at 3 X 100 gram scale to understand the process safety and impurity profile. It was gratifying to see the reproducibility was excellent. Next, our attention was to scale-up to produce kilogram quantities of the triazine $\mathbf{1}$. We commenced with the production of 2-cyanopyrrole. The Vilsmeier reagent was formed by addition of phosphorous oxychloride to DMF (10 volumes). Pyrrole was then added and allowed to react for $1 \mathrm{~h}$. Reactive phosphorous species were then quenched with water. Hydroxylamine hydrochloride was added followed by acetic anhydride addition to partially neutralize the acid generated from the reaction and oxidation process. ${ }^{13}$

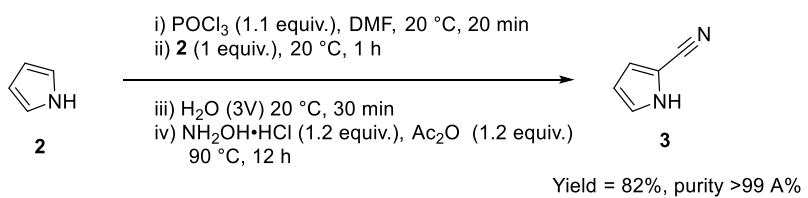

Results from the amination and reaction of the resultant amine with formamidine acetate to form the triazine translated well from 25 to $500 \mathrm{~g}$ scale. Yields were typically between $65-75 \%$ over the two steps. The number of equivalents of sodium hydride was examined and 1.1 equivalent was found to be the optimal condition in this process. Recrystallization of the mixture afforded high quality triazine (99.90 Area\%, 98.4 wt\%) with good recovery $(87.5 \%)$. 


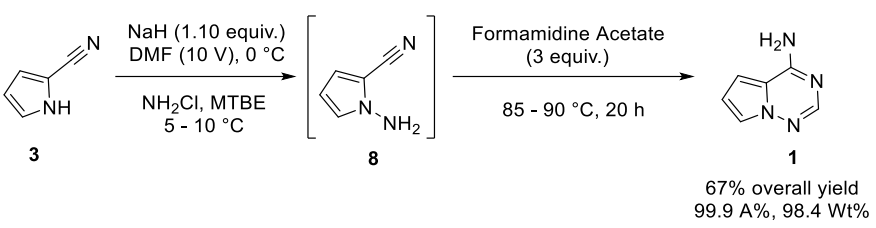

- Conclusion

In conclusion, we have described the process research, process safety and development parameters of the robust process for the scale-up of triazine 1. In addition, we demonstrated that the cyanation/amination/condensation sequence can be used to make kilogram quantities of $\mathbf{1}$ for remdesivir. Further, calorimetric safety studies indicate that the reactions are safe for scale-up operations according to the reaction parameters studied. A number of impurities generated in the synthetic process were identified, controlled and purification procedures were developed for the undesired compounds. Future efforts will be directed towards on demand production of chloramine via continuous flow chemistry and address the dilution effect in the amination step to improve the overall yield with high quality.

\section{- Experimental}

General: Commercially available solvents and reagents were used as received without further purification. All NMR data were recorded using Bruker $400 \mathrm{MHz}$ instrument. Reaction calorimetric data were collected using Mettler Toledo RC1 instrument. HPLC data were collected on Waters Alliance HPLC instruments with detection by UV. HPLC conditions were as follows: For 2-cyanopyrrole: Shimpack solar C18, 250 x 4.6 mm, $5 \mu \mathrm{m}, 95-40 \%$ gradient of water $(0.1 \%$ perchloric acid): Acetonitrile $(0.1 \%$ perchloric acid), flow rate $1.0 \mathrm{~mL} / \mathrm{min}$; acquisition time, $45 \mathrm{~min}$; UV at $245 \mathrm{~nm}$. B) For pyrrolo[2,1f][1,2,4]triazin-4-amine: Shimpack solar C18, 250 x $4.6 \mathrm{~mm}$, $5 \mu \mathrm{m}, 95-40 \%$ gradient of water $(0.1 \%$ perchloric acid) : Acetonitrile $(0.1 \%$ perchloric acid $)$, flow rate $1.0 \mathrm{~mL} / \mathrm{min}$; acquisition time, $45 \mathrm{~min}$; UV at $230 \mathrm{~nm}$. Purity was calculated through $\%$ area normalization. Monochloramine solution was assayed by titration using the following procedure:

Assay by titration $\left(\mathrm{NH}_{2} \mathrm{Cl}\right)(\% \mathrm{w} / \mathrm{w})$ :

SOLUTION A: $6.20 \mathrm{~g}$ of thiosulfate pentahydrate was added to $250 \mathrm{~mL}$ of deionized water and stirred until dissolved.

SOLUTION B: $0.500 \mathrm{~g}$ of pure starch was added to $50 \mathrm{~mL}$ of deionized water and heated to $70{ }^{\circ} \mathrm{C}$ for $1 \mathrm{~h}$.

SOLUTION C: To $200 \mathrm{~mL}$ of water $10 \mathrm{~mL}$ of glacial acetic acid, $10 \mathrm{~mL}$ of solution $\mathrm{B}$ and $0.8 \mathrm{~g}$ of potassium iodide was added.

In a conical flask $20.0 \mathrm{~mL}$ of solution $\mathrm{B}$ and $1.0 \mathrm{~mL}$ of sample were added. Under vigorous stirring, solution A was added until the solution turned colorless.

Assay $(\% \mathrm{w} / \mathrm{w})=\left(\mathrm{mL}\right.$ of $\left.\mathrm{Na}_{2} \mathrm{~S}_{2} \mathrm{O}_{3} \times 0.1 \mathrm{~N} \times 5.148\right)$

Sample weight (g) X 2

\section{Preparation of 2-cyanopyrrole (3).}

Phosphorus oxychloride (1.544 L, $16.56 \mathrm{~mol})$ was added slowly into well stirred and cooled $\left(0-5{ }^{\circ} \mathrm{C}\right)$ anhydrous DMF $(10 \mathrm{~L})$ over $3 \mathrm{~h}$, maintaining the reaction temperature at $0-5{ }^{\circ} \mathrm{C}$. The reaction mass was allowed to attain a temperature between 15 $20{ }^{\circ} \mathrm{C}$ and stirred for $30 \mathrm{~min}$ at this temperature. Reaction mass was cooled again to $0-5^{\circ} \mathrm{C}$ and pyrrole $(1 \mathrm{~kg}, 14.90 \mathrm{~mol})$ was added slowly to the cooled mixture over $1.5 \mathrm{~h}$, maintaining the reaction temperature below $15{ }^{\circ} \mathrm{C}$. The reaction mass was stirred for another $1 \mathrm{~h}$ at $15-20^{\circ} \mathrm{C}$ and cooled further to $0-5{ }^{\circ} \mathrm{C}$. Process water $(3 \mathrm{~L})$ was added slowly to the cooled reaction mass over $3 \mathrm{~h}$, maintaining the internal temperature of the mixture below $15^{\circ} \mathrm{C}$. The mixture was stirred at $15^{\circ} \mathrm{C}$ for $10 \mathrm{~min}$ and then solid hydroxylamine hydrochloride $(1.139 \mathrm{~kg}$, $16.41 \mathrm{~mol}$ ) was added into the mixture, followed by addition of acetic anhydride $(1.548 \mathrm{~L}, 16.48 \mathrm{~mol})$, maintaining the internal reaction temperature below $15^{\circ} \mathrm{C}$. The reaction mass was then heated to $90{ }^{\circ} \mathrm{C}$ and stirred for $12-16 \mathrm{~h}$ at this temperature. Reaction progress was monitored by HPLC and the heating was stopped when the quantity of unreacted intermediate aldehyde was found to be $<2 \mathrm{~A} \%$ by HPLC. The reaction mass was cooled to $25-30{ }^{\circ} \mathrm{C}$ and chilled $\left(10-15{ }^{\circ} \mathrm{C}\right)$ water $(10 \mathrm{~L})$ was added into it and stirred for $10 \mathrm{~min}$, followed by addition of MTBE (10 L) with stirring for another $10 \mathrm{~min}$. Stirring was stopped and the layers were allowed to separate. The aqueous layer was further extracted with MTBE $(2 \times 10 \mathrm{~L})$, and the combined organic extracts were washed successively with $2 \mathrm{~N} \mathrm{HCl}$ solution $(10 \mathrm{~L}), 10 \%$ aqueous sodium bicarbonate solution $(2 \times 10 \mathrm{~L})$ and dried over anhydrous sodium sulfate $(1 \mathrm{~kg})$. The mixture was filtered, and the solution was concentrated under reduced pressure at $40-50{ }^{\circ} \mathrm{C}$ to get the crude compound as a dark brown liquid. The crude material was then purified by fractional distillation at $100-140^{\circ} \mathrm{C}$ under high vacuum pressure (2$4 \mathrm{~mm} \mathrm{Hg}$ ) to get the following fractions with different assay percent for the desired compound (2-cyanopyrrole): $1^{\text {st }}$ fraction (containing mostly DMF and volatile impurities) $\left(50-70{ }^{\circ} \mathrm{C} / 2\right.$ $4 \mathrm{~mm} \mathrm{Hg}$ ) : $144.0 \mathrm{~g}$ (HPLC area\% : 99.15\%; assay: 18.20\%); $2^{\text {nd }}$ fraction $\left(95-100{ }^{\circ} \mathrm{C} / 2-4 \mathrm{~mm} \mathrm{Hg}\right): 348.0 \mathrm{~g}$ (HPLC area\%: 99.54\%; assay: $92.25 \%) ; 3^{\text {rd }}$ fraction $\left(100-125{ }^{\circ} \mathrm{C} / 2-4 \mathrm{~mm} \mathrm{Hg}\right.$ ) : 870.0 g (HPLC area\% : 99.38\%; assay: $89.2 \%$ ). Overall assaybased yield: $81.8 \%$, Chemical purity: $>99 \%$ (excluding DMF) ${ }^{1} \mathrm{H}$ NMR (400 MHz, DMSO-d $\mathrm{d}_{6}$ ): $\delta 12.27$ (br s, 1H), 7.13 (s, $1 \mathrm{H}), 6.94-6.89(\mathrm{~m}, 1 \mathrm{H}), 6.21(\mathrm{~s}, 1 \mathrm{H}) .{ }^{13} \mathrm{C} \mathrm{NMR}(100 \mathrm{MHz}$, DMSO-d $)_{6}: \delta 124.62,119.37,114.86,109.50,99.58$. GCMS $(\mathrm{m} / \mathrm{z}): 92.1$

\section{Preparation of pyrrolo[2,1-f][1,2,4]triazin-4-amine (1).}

Preparation of Monochloramine in MTBE: To a cooled (-8 $\left.\pm 2{ }^{\circ} \mathrm{C}\right)$ and stirred mixture of MTBE $(36.0 \mathrm{~L})$ and $\mathrm{NH}_{4} \mathrm{Cl}(2.7$ $\mathrm{kg}, 50.47 \mathrm{~mol}$ ) in a reactor (fitted with an internal temperature probe, addition flask and nitrogen line) was added aqueous ammonia solution $(25 \%, 4.21 \mathrm{~L})$, maintaining the internal temperature at $-8 \pm 2{ }^{\circ} \mathrm{C}$. Then pre-cooled (below $5{ }^{\circ} \mathrm{C}$ ) sodium hypochlorite solution (chlorine content: $8-10 \%, 47.4 \mathrm{~L}$ ) was added into the reaction mixture via addition flask over 50-80 $\mathrm{min}$, keeping the internal temperature at $-8 \pm 2{ }^{\circ} \mathrm{C}$. The reaction mass was stirred for $30 \mathrm{~min}$ at $-8 \pm 2{ }^{\circ} \mathrm{C}$ and then the aqueous and organic layers were allowed to separate for a period of 30-60 $\min$ at $-8 \pm 2{ }^{\circ} \mathrm{C}$. The organic layer was separated, washed with pre-cooled $\left(0-5{ }^{\circ} \mathrm{C}\right)$ brine solution $(12 \mathrm{~L})$, and dried over anhydrous $\mathrm{CaCl}_{2}(1.2 \mathrm{~kg})$ at $0-5{ }^{\circ} \mathrm{C}$. The dried sample was checked for monochloramine content $(\sim 2.2 \%)$. The dried solution was kept in the reactor at -5 to $0{ }^{\circ} \mathrm{C}$ for use in the reaction of preparation of triazine compound as described below.

Preparation of pyrrolo[2,1-f][1,2,4]triazin-4-amine: Sodium hydride (60\% dispersion in mineral oil, $0.29 \mathrm{~kg}, 7.17 \mathrm{~mol})$ was added into stirred anhydrous DMF $(6.0 \mathrm{~L})$ at $0-5{ }^{\circ} \mathrm{C}$ and the mixture was stirred further at $0-5{ }^{\circ} \mathrm{C}$ for $20-30$ min under $\mathrm{N}_{2}$ atmosphere. Then 2-cyanopyrrole $(0.60 \mathrm{~kg}, 6.52 \mathrm{~mol})$ was 
added into the reaction mixture at $0-5{ }^{\circ} \mathrm{C}$ under $\mathrm{N}_{2}$ atmosphere (gas evolution occurs), maintaining the internal temperature between $5-10{ }^{\circ} \mathrm{C}$ and stirred for $30-40 \mathrm{~min}$ at this temperature. The monochloramine solution in MTBE $(2.2 \%)(30 \mathrm{~V}, 18 \mathrm{~L})$ was added into the reaction mixture while maintaining the internal temperature between $0-5{ }^{\circ} \mathrm{C}$ (reaction mass becomes yellowish to brown color during addition). Reaction progress was monitored by HPLC analysis. Unreacted pyrrole-2-carbonitrile was $\sim 6 \%$ and KI-starch strip showed absence of monochloramine and $\mathrm{pH}$ of the reaction showed $>10$ by $\mathrm{pH}$ strip. Next, another $10 \mathrm{~V}$ of monochloramine solution in MTBE $(2.2 \%, 6 \mathrm{~L}$ i.e. total $24 \mathrm{~L}(40 \mathrm{~V})$, density $0.768 \mathrm{~kg} / \mathrm{m}^{3}, 7.87 \mathrm{~mol}, 1.2$ equiv.) was added to the reaction mixture and the reaction proceeded for 1 h to afford $N$-amino-2-cyanopyrrole 7 with $1.8 \%$ of unreacted 2-cyanopyrrole Formamidine acetate $(2.04 \mathrm{~kg}, 19.56 \mathrm{~mol}, 3$ equiv.) was added into the reaction mixture at $0-5{ }^{\circ} \mathrm{C}$ and reaction mixture was then heated to $85-90{ }^{\circ} \mathrm{C}$. Simultaneously the MTBE was distilled from the reaction mixture at atmospheric pressure until the internal temperature reached $85-90{ }^{\circ} \mathrm{C}$. The reaction mixture was stirred at $85-90{ }^{\circ} \mathrm{C}$ for $20 \mathrm{~h}$, and after that the sample of the reaction mixture was analyzed by HPLC analysis to check the consumption of intermediate ( $N$-amino-2-cyanopyrrole 8) $(\sim 0.14 \mathrm{~A} \%)$. The reaction mixture was cooled to $25-30{ }^{\circ} \mathrm{C}$ and then filtered. The filter cake was washed with DMF $(0.6 \mathrm{~L})$ and the combined filtrate was concentrated to $\sim 4$ $\mathrm{V}$, keeping the temperature below $70{ }^{\circ} \mathrm{C}$ under reduced pressure. The residual mass was cooled to $25-30{ }^{\circ} \mathrm{C}$, and water $(2.4$ L) was added slowly into the cooled mass with stirring for $1 \mathrm{~h}$ at $25-30{ }^{\circ} \mathrm{C}$. The mixture was then cooled further to $5-10{ }^{\circ} \mathrm{C}$ and stirred for $2 \mathrm{~h}$ at this temperature. The stirring was stopped and the solids were isolated by filtration. The cake was washed with water $(0.6 \mathrm{~L})$, under applied vacuum to dry. The cake was then washed with MTBE (1.2 L, 2V). The wet cake was dried under vacuum at $50-55{ }^{\circ} \mathrm{C}$ for 5-6 h until constant weight was obtained. The yield of pyrrolo[2,1-f][1,2,4] triazin-4-amine (crystalline material, 1) was $0.69 \mathrm{~kg}(67 \%)$. ${ }^{1} \mathrm{H}$ NMR $(400$ MHz, DMSO-d 6 ): $\delta 7.78(\mathrm{~s}, 1 \mathrm{H}), 7.68($ br s, 2H), 7.59-7.58 (m, 1H), 6.86-6.84 (m, 1H), 6.60-6.58 (m, 1H). ${ }^{13} \mathrm{C}$ NMR $(100$ MHz, DMSO-d $\left.{ }_{6}\right): \delta 155.5,147.9,118.1,114.3,110.0,101.2$. GC-MS (m/z): 134.1. HPLC Purity: (230.0 nm): 99.9 A\%, 98.4 $\mathrm{Wt} \%$.

\section{ASSOCIATED CONTENT}

The Supporting Information is available free of charge on the ACS Publications website.

\section{AUTHOR INFORMATION}

\section{Corresponding Author}

*\$ David R. Snead, drsnead@ vcu.edu

*\$Chris H. Senanayake, chris.senanayake@tcgls.com

\author{
Medicines for All Institute \\ 737 N 5th St. \\ Box 980100 \\ Richmond, Virginia 23298
}

${ }^{\S}$ TCG GreenChem, Inc.

737 North 5th Street, Suite 467

Richmond, VA 23219, USA.

\section{${ }^{\dagger}$ TCG Lifesciences Private Limited}

Kolkata - R\&D Centre, Chemistry

Block BN, Plot 7

Salt Lake Electronics Complex

Sector V, Kolkata - 700091

West Bengal, India

\section{ACKNOWLEDGMENT}

We thank the Bill and Melinda Gates Foundation for their longstanding support of our research. We would like to express gratitude to Trevor Laird and John Dillon for insightful discussions and suggestions.

\section{REFERENCES}

1) a) Siegel, D.; Hui, H.C.; Doerffler, E.; Clarke, M.O.; Chun, K.; Zhang, L.; Neville, S.; Carra, E.; Lew, W.; Ross, B.; Wang, Q.; Wolfe, L.; Jordan, R.; Soloveva, V.; Knox, J.; Perry, J.; Perron, M.; Stray, K.M.; Barauskas, O.; Feng, J.Y.; Xu, Y.; Lee, G.; Rheingold, A.L.; Ray, A.S.; Bannister, R.; Strickley, R.; Swaminathan, S.; Lee, W.A.; Bavari, S.; Cihlar, T.; Lo, M.K.; Warren, T.K.; Mackman, R.L. J. Med. Chem., 2017, 60, 1648-1661.

2) a) Vieira, T.; Stevens, A.C.; Chtchemelinine, A.; Gao, D.; Badalov, P.; Heumann, L. Org. Process Res. Dev., 2020, ASAP. b) Xue, F.; Zhou, X.; Zhou, R.; Zhou, X.; Xiao, D.; Gu, E.; Guo, X.; Xiang, J.; Wang, K.; Yang, L.; Zhong, W.; Qin, Y. Org. Process Res. Dev., 2020, 24, 1772-1777. c) Wang, M.; Zhang, L.; Huo, X.; Zhang, Z.; Yuan, Q.; Li, P.; Chen, J.; Zou, Y.; Wu, Z.; Zhang, W. Angew. Chem., Int. Ed. 2020, 59, ASAP. d) Bigley, A.N.; Narindoshvili, T.; Raushel, F.M. Biochemistry, 2020, 59, 3038-3043. e) von Keutz, T.; Williams, J.D.; Kappe, C.O. Org. Process Res. Dev., 2020, 24, $2362-$ 2368. b) De Savi, C.; Hughes, D.L.; Kvaerno, L. Org. Process Res. Dev., 2020, 24, 940-976.

3) Paymode, D.J.; Cardoso, F.S.P.; Agrawal, T.; Tomlin, J.W.; Cook, D.W.; Burns, J.M.; Stringham, R.W.; Sieber, J.D.; Gupton, B.F.; Snead, D.R. Org. Lett., 2020, 22, 7656-7661.

4) a) Dixon, J.A.; Phillips, B.; Achebe, F.; Kluender, H.C.E.; Newcom, J.; Parcella, K.; Magnuson, S.; Hong, Z.; Zhang, Z.; Liu, Z.; Khire, U.; Wang, L.; Michels, M.; Chandler, B.; O'Connor, S. US8143393, 2006. b) O'Connor, S.; Dumas, J.; Lee, W.; Dixon, J.; Cantin, D.; Gunn, D.; Burke, J.; Phillips, B.; Lowe, D.; Shelekhin, T.; Wang, G.; Ma, X.; Ying, S.; McClure, A.; Achebe, F.; Lobell, M.; Ehrgott, F.; Iwuagwu, C.; Parcella, K. US8431695, 2006.

5) Achmatowicz, M.M.; Thiel, O.R.; Colyer, J.T.; Hu, J.; Elipe, M.V.S.; Tomaskevitch, J.; Tedrow, J.S.; Larsen, R.D. Org. Process Res. Dev., 2010, 14, 1490-1500.

6) Yang, Q.; Sheng, M.; Henkelis, J.J.; Tu, S.; Wiensch, E.; Zhang, H.; Zhang, Y.; Tucker, C.; Ejeh, D.E. Org. Process Res. Dev., 2019, 23, 2210-2217.

7) a) Jolly, W.L. J. Phys.Chem., 1956, 60, 507-508. b) Drago, R.S. J. Chem. Ed., 1957, 34, 541-545. c) Okada, K.; Akiyoshi, M.; Ishizaki, K.; Sato, H.; Matsunaga, T. J. Hazard. Mater., 2014, 278, 75-81.

8) van den Broek, S.A.M.W.; Leliveld, J.R.; Becker, R.; Delville, M.M.E.; Nieuwland, P.J.; Koch, K.; Rutjes, F.P.J.T. Org. Process Res. Dev., 2012, 16, 934-938.

9) a) Ura, Y.; Sakata, G. "Chloramines", in Ullmann's Encyclopedia of Industrial Chemistry, Weinham, Germany: WileyVCH Verlag GmbH \& Co. KGaA, 2000. b) Lutze, H.V. “Wa- 
ter, 6. Treatment by Oxidation Processes" in Ullmann's Encyclopedia of Industrial Chemistry, Weinham, Germany: Wiley-VCH Verlag GmbH \& Co. KGaA, 2000.

10) Smith, G.F. Adv. Heterocycl. Chem., 1963, 2, 287-309.

11) a) Somei, M.; Matsubara, M.; Kanda, Y.; Natsume, M. Chem. Pharm. Bull., 1978, 26, 2522-2534. b) Hynes, J.; Doubleday, W.W.; Dyckman, A.J.; Godfrey, J.D.; Grosso, J.A.; Kiau, S.; Leftheris, K. J. Org. Chem., 2004, 69, 1368-1371.

12) Quench protocol was examined with or without sodium acetate in DMF 10 volumes and 5 volumes respectively. In addition, we also examined pyridine and acetic anhydride, acetic anhydride alone to understand the reaction profile and the safety profile. It is important to note that, DMF 10 volumes, acetic anhydride addition provided the best profile for this process.

13) Impurity 9 data: ${ }^{1} \mathrm{HNMR}\left(400 \mathrm{MHz}, \mathrm{DMSO}-\mathrm{d}_{6}\right): \delta 8.18$ (s, $1 \mathrm{H}), 7.21(\mathrm{bs}, 1 \mathrm{H}), 6.76(\mathrm{~m}, 1 \mathrm{H}), 6.1(\mathrm{t}, J=3.76 \mathrm{~Hz}, 1 \mathrm{H}), 2.94$ (s, 3H), $2.87(\mathrm{~s}, 3 \mathrm{H}) .{ }^{13} \mathrm{C} \mathrm{NMR}\left(100 \mathrm{MHz}, \mathrm{CDCl}_{3}\right): \delta 158.96$, 122.01, 116.87, 113.84, 106.94, 101.83, 40.90, 35.90; LCMS $(\mathrm{M}+\mathrm{H})=163$. 